\title{
PERKEMBANGAN EMBRIO DAN LARVA IKAN LETTER SIX, Paracanthurus hepatus
}

\author{
Daniar Kusumawati"), Ketut Maha Setiawati"), dan Bambang Priono") \\ ") Balai Besar Penelitian dan Pengembangan Budidaya Laut \\ ") Pusat Penelitian dan Pengembangan Perikanan Budidaya
}

(Naskah diterima: 30 Januari 2015; Revisi final: 28 April 2015, Disetujui publikasi: 5 Juni 2015)

\begin{abstract}
ABSTRAK
Dalam upaya memperkaya populasi ikan letter six (Paracanthurus hepatus) di alam yang telah mendekati kepunahan akibat adanya illegal fishing maka dilakukan usaha perbenihan. Kegiatan perbenihan ikan letter six memerlukan informasi awal tentang perkembangan telur dan pemeliharaan larva yang nantinya akan digunakan sebagai acuan dasar dalam menentukan pengembangan teknik pemeliharaan larva ikan letter six yang tepat. Koleksi induk ikan letter six hasil tangkapan di alam dari perairan Maluku dan Papua. Induk letter six dipelihara dalam tangki policarbonat bulat berkapasitas dua ton dengan sistem air mengalir. Selama pemeliharaan, induk letter six mampu memijah secara alami. Durasi perkembangan embrio hingga menetas memerlukan waktu 22 jam 24 menit pada suhu normal air laut $29^{\circ} \mathrm{C}$. Penyerapan kuning telur optimum terjadi pada hari kedua dan maksimum terserap habis pada hari ketiga, sedangkan butir minyak terserap habis tepat pada hari ketiga. Korelasi pertumbuhan panjang dan tinggi larva mengikuti hubungan alometrik negatif di mana konstanta pertumbuhan $b=0,6629(b<1)$. Berdasarkan perkembangan larva, umur D-2 (terbentuk bintik mata) mulai diberikan pakan alami berupa plankton dan pada D-3 (bukaan mulut) mulai diberikan zooplankton yaitu rotifer. Dengan metode pemeliharaan ini, larva ikan letter six mati pada D-25 sehingga perlu adanya perbaikan metode pemeliharaan melalui pendekatan lingkungan maupun pakan.
\end{abstract}

\section{KATA KUNCI: larva, letter six, embrio, morfologi, Paracanthurus hepatus}

ABSTRACT: Morphological development of embryo and larval of letter six, Paracanthurus hepatus. By: Daniar Kusumawati, Ketut Maha Setiawati, and Bambang Priono

\begin{abstract}
In efforts to enhance the population of letter six fish (Paracanthurus hepatus) in nature that has been almost indanger due to illegal fishing, artificial seed production have been made. In seed production activities of letter six some basic biological information is necessary. This study observed embryonic and larval development of letter six as preliminary study to support further seed production technology of letter six. The broodstock of letter six were collected from coastal water of Maluku and Papua. The broodstock were kept on circle polycarbonate tank with a capacity of two tons. The duration of embryonic development takes 22 hours 24 minutes to hatch at water temperature of $29^{\circ} \mathrm{C}$. Optimum yolk sack absorption was occured on the second day and completely absorbed at $3^{\text {rd }}$ day, while the oil globule was completely absorbed $3^{\text {rd }}$ day. The correlation growth of length and height of larvae followed negative allometric relationship $(b=0.6629(b<1))$. Based on the larval development, plankton have to be given on $D-2$ and followed rotifer at D-3. In the present preliminary study the letter six larvae survived up to 25 days.
\end{abstract}

KEYWORDS: $\quad$ larvae, letter six, embryo, morphology, Paracanthurus hepatus

\section{PENDAHULUAN}

Paracanthurus hepatus yang memiliki nama lokal letter six di Indonesia dan nama market palette surgeonfish, termasuk dalam family Acanthuridae dengan corak warna dominan biru cerah dengan warna hitam berbentuk angka 6 di kedua sisi badannya dan warna

\# Korespondensi: Balai Besar Penelitian dan Pengembangan Budidaya Laut. Jl. Br. Gondol Kec. Gerokgak Kab. Buleleng, Kotak Pos 140, Singaraja, Bali 81101, Indonesia. Tel.: + (0362) 92278 E-mail: ornamental_research@yahoo.co.id kuning dengan garis hitam pada ekornya. Habitatnya berada pada daerah terumbu karang dengan kisaran kedalaman 2-25 m dan area penyebarannya meliputi kawasan Indo-Pasifik antara lain Afrika Timur hingga Indonesia, Micronesia, Samoa, New Caladonia, dan Barat Daya Jepang hingga Great Barrier Reef (Allen et al., 2003). Ikan ini termasuk salah satu ikan hias yang marketable di Bali, sehingga keberadaannya mulai terancam akibat adanya penangkapan liar oleh para nelayan (Reksodihardjo \& Lilley, 2007). Terkait dengan permasalahan tersebut, maka dilakukan upaya kon- 
servasi melalui usaha perbenihan ikan letter six di Balai Besar Penelitian dan Pengembangan Budidaya Laut (BBPPBL), Gondol, Buleleng, Bali.

Dalam perkembangan perbenihan ikan letter six, telah dilakukan upaya domestikasi induk-induk dari alam ke dalam lingkungan terkontrol, bertujuan: (1) untuk mengumpulkan dan menyimpan suatu individu untuk tujuan tertentu, (2) diharapkan individu yang telah terkumpul dapat dibenihkan secara terkontrol, (3) sebagai langkah awal untuk mempelajari perilaku suatu individu/spesies di mana variasi morfologi dan fisiologi saat dalam lingkungan alam masih belum diketahui, (4) dan beberapa spesies tertentu tidak dapat bertahan tanpa perlindungan manusia (Balon, 2004). Upaya domestikasi telah berhasil dilakukan dengan adanya indikasi tingginya sintasan induk, memiliki respons makan terhadap pakan buatan (pellet), keberhasilan pemijahan secara alami oleh induk-induk ikan letter six di BBPPBL, Gondol, Buleleng, Bali. Terkait dengan keberhasilan pemijahan induk ikan letter six, perlu adanya langkah lebih lanjut untuk mengembangkan teknik pemeliharaan yang tepat pada larva. Informasi perkembangan dan tingkah laku larva ikan letter six pada kondisi alam belum diketahui, maka perlu dilakukan observasi awal yang bertujuan untuk memperoleh data perkembangan telur dan pemeliharaan larva yang nantinya akan digunakan sebagai acuan dasar dalam menentukan pengembangan teknik pemeliharaan larva ikan letter six yang tepat.

\section{BAHAN DAN METODE}

\section{Pemeliharaan dan Pemijahan Induk}

Induk dipelihara dalam tangki polikarbonat berbentuk bulat kapasitas dua ton dengan kepadatan 34 ekor/bak dengan perbandingan induk jantan dan betina adalah $1: 1$. Induk betina memiliki rataan panjang total 16,1 $\pm 1,7 \mathrm{~cm}$ dengan kisaran bobot badan 101,5 $\pm 31,6 \mathrm{~g}$; sedangkan induk jantan memiliki rataan panjang total $14,9 \pm 1,7 \mathrm{~cm}$ dengan kisaran bobot badan 78,1 $\pm 31,7 \mathrm{~g}$. Seluruh induk diperoleh dari tangkapan alam di perairan Maluku dan Irian Jaya. Induk diberi pakan berupa pelet komersil, cacing Nereis, udang rebon, ikan teri, rumput laut (Gracilaria, Caulerpa, Euchema) dengan frekuensi pemberian pakan dua kali/hari. Pergantian air menggunakan sistem flow throw dengan persentase sekitar $400 \%$. Setiap minggu sekali dilakukan penyiponan, serta pembersihan dasar bak pemeliharaan induk dan kolektor telur.

\section{Perkembangan Embrio}

Pengamatan perkembangan embrio dan larva letter six dilakukan di laboratorium Balai Besar Penelitian dan Pengembangan Budidaya Laut, Gondol. Telur yang diamati diperoleh melalui pemijahan alami dari induk- induk yang telah dipelihara selama satu tahun. Telur diletakkan ke dalam inkubasi plate yang diletakkan di atas shaker dengan kecepatan $400 \mathrm{rpm}$ dalam inkubator Eyela Multi Thermo Incubator MTI-202 dengan kisaran suhu $28^{\circ} \mathrm{C}$. Pada stadia awal pembelahan sel hingga stadia blastula, pengamatan dilakukan setiap lima menit. Kemudian pengamatan dilanjutkan setiap 30 menit hingga memasuki stadia terbentuk jantung, kemudian pengamatan dilakukan setiap jam hingga menetas. Pengamatan perkembangan embrio letter six dilakukan dengan menggunakan mikroskop Nikon eclipse E 600 dan pengambilan gambar menggunakan kamera digital Nikon Digital Camera DXM 1200F pada mikroskop yang terhubung dengan program Image Analyzer ACT 1 pada komputer. Pengukuran diameter telur maupun butir minyak menggunakan program winroof V5.0. Penghitungan durasi perkembangan embrio letter six ditentukan sesaat setelah fertilisasi.

\section{Pemeliharaan dan Perkembangan Larva}

Pemeliharaan larva letter six dilakukan secara massal dengan kepadatan 1-20 ekor/L pada bak fiber volume satu ton dengan kisaran suhu pemeliharaan $26^{\circ} \mathrm{C}-28^{\circ} \mathrm{C}$. Pemberian pakan larva berupa fitoplankton (Nannochloropsis sp.) dan rotifer dengan konsentrasi minimal masing-masing $200.000 \mathrm{sel} / \mathrm{mL}$ dan 20 ekor/ $\mathrm{mL}$. Pengamatan perkembangan morfologi larva letter six dilakukan setiap hari dengan mengamati ukuran panjang larva, diameter, dan volume butir minyak dan kuning telur, pigmentasi pada tubuh larva, perkembangan sirip, isi perut, dan bukaan mulut larva. Volume kuning telur dan butir minyak dihitung menurut rumus:

$$
V e=\frac{\pi}{6} \times 1 \times h^{2} \text { dan } V=\frac{4}{3} \times \pi \times r^{3}
$$

di mana:

$\mathrm{l}$ dan h adalah panjang dan tinggi kuning telur, sedangkan $r$ adalah jari-jari butir minyak (Bonislawska et al., 2004).

\section{Analisis Data}

Data perkembangan embrio dan larva dilakukan secara deskriptif. Pertumbuhan allometrik dan laju penyerapan endogenous dilakukan analisis regresi untuk mendapatkan persamaan korelasi (Snedecor \& Cochran, 1989). Pertumbuhan allometrik diestimasikan dalam bentuk transformasi data logaritma dengan persamaan $\mathrm{y}=\mathrm{a} \mathrm{L}^{\mathrm{b}}$ di mana: $\mathrm{a}$ adalah intersep dan $\mathrm{b}$ adalah koefisien pertumbuhan (Gisbert et al., 2002). Pertumbuhan isometrik terjadi apabila nilai koefisien $b=3$, sedangkan pertumbuhan allometrik positif terjadi apabila nilai koefisien $b>3$ dan sebaliknya pertumbuhan allometrik negatif terjadi apabila $\mathrm{b}<3$. 


\section{HASIL DAN BAHASAN}

\section{Pemijahan Induk dan Perkembangan Embrio}

Letter six memijah pada saat menjelang malam hari yaitu sekitar pukul 18.00 WITA. Telur ikan letter six berbentuk bulat dan melayang di permukaan air dan pada awal stadia pembelahan sel memiliki diameter $0,69 \pm 0,006 \mathrm{~mm}$ dengan volume butir minyak 0,019 $\pm 0,001 \mathrm{~mm}^{3}$. Berbeda dengan ikan hias clown hitam (Amphiprion percula) yang memiliki bentuk lonjong dengan kisaran ukuran yang relatif lebih besar dari telur ikan letter six dengan ukuran 2,21 x 0,89 mm (Kusumawati \& Setiawati, 2010). Sedangkan pada ikan clown biasa (Amphiprion ocellaris) memiliki bentuk lonjong dengan ukuran 1,8 x 0,8 mm (Yasir \& Qin, 2007), sementara itu, pada jenis ikan clown lainnya yaitu Amphiprion akallopisos memiliki kisaran ukuran 2,21 x $1 \mathrm{~mm}$ (Dhaneesh et al., 2011). Pada ikan hias lainnya yaitu dari jenis ikan goby (Priolepis nocturna) memiliki bentuk oval dengan ukuran lebih besar dari ukuran telur ikan letter six yaitu 0,82 x 0,51 mm (Wittenrich et al., 2007). Pada jenis ikan hias laut dengan ukuran telur yang relatif besar dan berbentuk oval umumnya tidak melayang tetapi menempel pada substrat. Sementara itu, pada jenis ikan hias dari jenis angel (Centropyge flavissimus) telur yang dipijahkan melayang dan berbentuk bulat dengan ukuran yang sama dengan ikan letter six yaitu $0,7 \mathrm{~mm}$ (Olivotto et al., 2006).

Durasi perkembangan embrio ikan letter six terjadi dalam waktu 22 jam 24 menit (Tabel 1). Dalam kondisi suhu air yang sama yaitu berkisar $27^{\circ} \mathrm{C}-28^{\circ} \mathrm{C}$, perkembangan embrio ikan letter six relatif lebih ce- pat jika dibandingkan dengan ikan hias laut dari jenis Amphiprion di mana pada ikan $A$. ocellaris dan $A$. kallopisos memerlukan waktu yang sangat lama yaitu 152 jam (Yasir \& Qin, 2007; Dhaneesh et al., 2011). Sedangkan pada ikan jenis goby (Priolepis nocturna) memerlukan waktu 96 jam untuk larva bisa menetas (Wittenrich et al., 2007). Pada jenis-jenis ikan hias air laut yang memerlukan waktu lama untuk menetas merupakan ikan yang bersifat parental care khususnya pada pejantannya. Pada ikan angel (Centropyge flavissimus) memerlukan waktu selama 15 jam hingga larva menetas (Olivotto et al., 2006).

Stadia perkembangan embrio pada setiap ikan adalah sama, namun durasi tiap stadia yang membedakan. Pada ikan letter six awal perkembangan diawali dengan pembelahan satu sel kemudian menjadi dua sel pada waktu 20 menit. Kemudian berturut-turut membelah menjadi 4, 8, 16,32, dan banyak sel masingmasing pada waktu 47 menit, 1 jam 12 menit, 1 jam 31 menit, 1 jam 47 menit, dan 2 jam 3 menit (Gambar 1).

Setelah pembelahan sel terjadi sempurna, kemudian memasuki stadia blastula (Gambar $1 \mathrm{~h}$ ) pada waktu 3 jam 21 menit. Dari stadia blastula memasuki awal stadia gastrula (Gambar 1i) pada waktu 5 jam 36 menit, di mana pada fase ini blastoderm mulai terlihat namun masih berada di bagian dasar sumbu. Pada stadia pertengahan gastrula (Gambar $1 \mathrm{j}$ ) terjadi pada waktu 8 jam 25 menit, di mana balstoderm telah berada pada pertengahan permukaan telur. Pada akhir fase gastrula (Gambar 1k) yang terjadi pada waktu 9 jam 53 menit, di mana blastoderm sudah mulai menutupi hampir semua seluruh permukaan telur se-

Tabel 1. Durasi perkembangan embrio ikan letter six, Paracanthurus hepatus

Table 1. The duration of embryonic development of letter six, Paracanthurus hepatus

\begin{tabular}{|c|c|}
\hline $\begin{array}{c}\text { Perkembangan stadia embrio } \\
\text { Embryonic development }\end{array}$ & $\begin{array}{l}\text { Waktu setelah dibuahi } \\
\text { Time after fertilization }\end{array}$ \\
\hline Pembelahan sel (Cleveage stage) & 2:03 jam (2:03 hours $)$ \\
\hline Blastula & 3:25 jam (3:25 hours) \\
\hline Gastrula & 9:53 jam (9:53 hours) \\
\hline \multicolumn{2}{|l|}{ Embriogenesis: } \\
\hline - Pembentukan bayangan embrio (Appearance of embryonic shield) & $11: 10$ jam (11:10 hours $)$ \\
\hline - Pembentukan embrio (Advanced embryo) & $12: 25$ jam (12:25 hours $)$ \\
\hline - Stadia 4 myomere (Fourth stage of myomere) & 13:25 jam (13:25 hours) \\
\hline - Stadia 9 myomere (Nineth stage of myomere) & $15: 14$ jam (15:14 hours $)$ \\
\hline - Stadia 11 myomere (Eleventh stage of myomere) & $16: 23$ jam (16:23 hours) \\
\hline - Stadia 15 myomere (Fifteenth stage of myomere) & 17:08 jam (17:08 hours) \\
\hline - Jantung berdetak (Heart beating) & 19:19 jam (19:19 hours) \\
\hline - Ekor bergerak (Moving tail) & $21: 13$ jam (21:13 hours $)$ \\
\hline - Menetas (Pre-hatch) & $22: 24$ jam (22:24 hours) \\
\hline
\end{tabular}




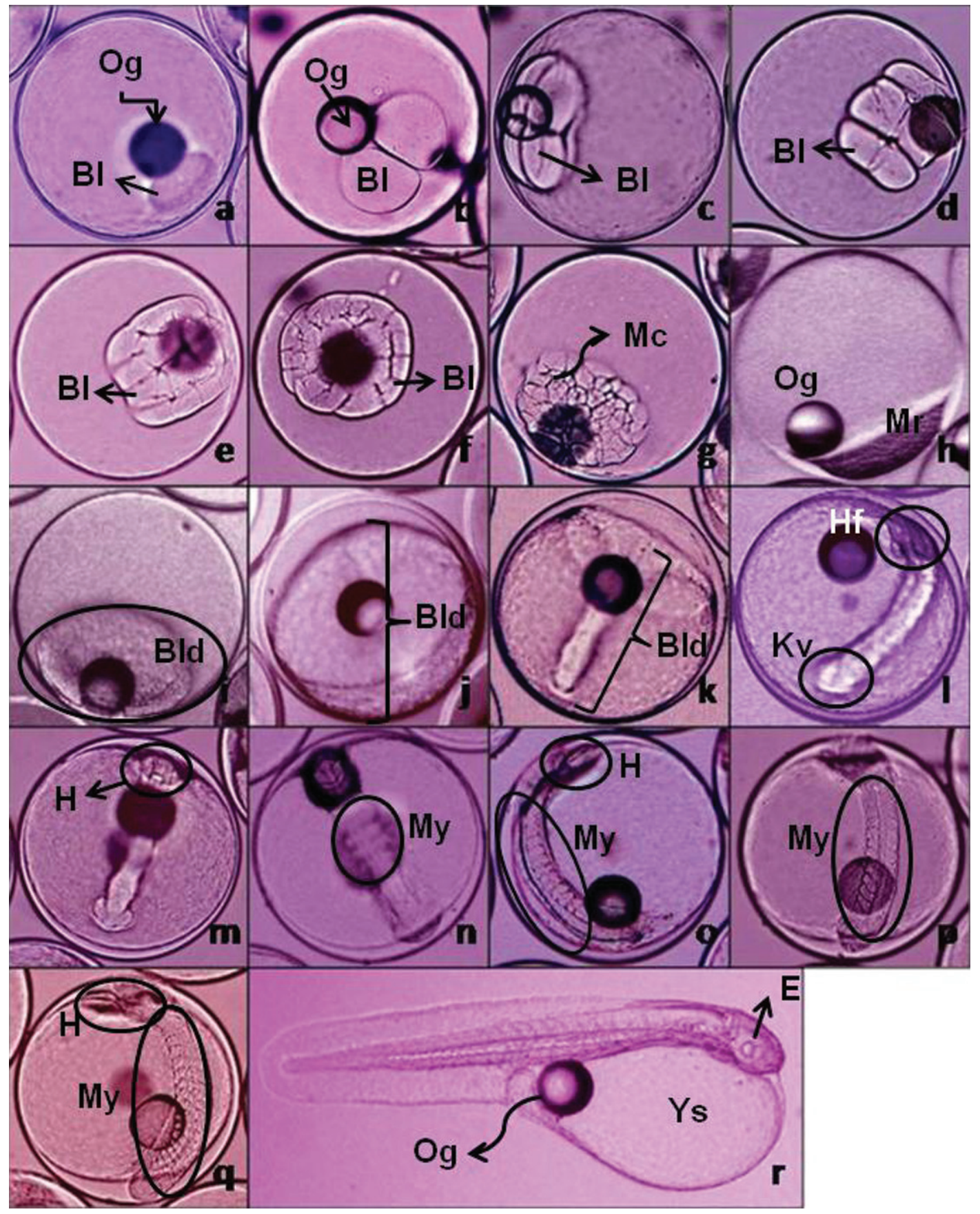

Gambar 1. Perkembangan embrio ikan letter six, Paracanthurus hepatus; (a) 1 sel (10x), (b) 2 sel (10x), (c) 4 sel (10x), (d) 8 sel (10x), (e) 16 sel (10x), (f) 32 sel (10x), (g) multisel (10x), (h) blastula (4x), (i) awal gastrula (4x), (j) gastrula pertengahan (4x), (k) akhir gastrula (4x), (l) bayangan embrio (10x), (m) pembentukan embrio (10x), (n) stadia 4 myomere (4x), (o) stadia 9 myomere (4x), (p) stadia 11 myomere (4x), (q) stadia 16 myomere (10x), (r) larva menetas (4x). Og (butir minyak); Bl (blastomere); Mc (multisel); $\mathrm{Mr}$ (morula); Bld (blastoderm); Hf (bakal kepala); Kv (kupffer’s vesicle); H (kepala); My (myomere); Ys (kuning telur); E (mata)

Figure 1. Embryonic development of letter six, Paracanthurus hepatus; (a) 1 cell (magnifiying 10x), (b) 2 cell (10x), (c) 4 cell (10x), (d) 8 cell (10x), (e) 16 cell (10x), (f) 32 cell (10x), (g) multicell (10x), (h) blastula stage (4x), (i) early gastrula (4x), (j) middle gastrula (4x), (k) late gastrula (4x), (l) appearance of embryonic shield (10x), (m) advanced of embryo (10x), (n) fourth stage of myomere (4x), (o) nineth stage of myomere (4x), (p) eleventh stage of myomere (4x), (q) sixteenth stage of myomere (10x), (r) pre-hatch larvae (4x). Og (oil globule); Bl (blastomeres); Mc (multicells); $\mathrm{Mr}$ (morulla); Bld (blastoderm); $\mathrm{Hf}$ (head formed); Kv (kupffer's vesicle); $H$ (head); $M y$ (myomere); Ys (yolk sac); $E$ (eye) 
hingga mulai menampakan bayangan bakal calon embrio.

Dengan berakhirnya stadia gastrula, maka mulai memasuki stadia akhir yaitu organogenesis. Fase organogenesis terbagi dalam beberapa fase, yang pertama adalah fase pembentukan bayangan embrio (Gambar 1l) yang terjadi pada waktu 11 jam 10 menit, di mana pada fase ini embrio masih berupa selubung bayangan yang masih belum nampak jelas. Fase kedua yaitu pembentukan embrio yang terjadi pada waktu 12 jam 25 menit, di mana embrio telah nampak jelas dengan pembentukan bakal kepala pada anterior permukaan telur dan terbentuk kupffer's vesicle pada posterior ujung bakal ekor. Pada pembentukan embrio, akan terbentuk myomere atau segmen pada bagian tengah embrio. Fase 4 myomere (Gambar 1n) terjadi pada waktu 13 jam 25 menit, kemudian myomere semakin meningkat jumlahnya menjadi 9 (Gambar 1o) yang terjadi pada waktu 15 jam 14 menit. Semakin bertambah umur larva, jumlah myomere juga makin bertambah menjadi 11 myomere (Gambar 1p) hingga 15 myomere (Gambar 1q) yang masing-masing terjadi pada waktu 16 jam 23 menit dan 17 jam 8 menit. Fase berikutnya dari stadia organ ogenesis adalah berdetaknya jantung yang terjadi pada waktu 19 jam 19 menit. Pada stadia akhir organogenesis ditandai dengan bergeraknya ekor yang terjadi pada waktu 21 jam 13 menit, dan awal penetasan terjadi pada waktu 22 jam 24 menit, di mana embrio menetas menjadi larva (Gambar 1r).

\section{Penyerapan Endogenous}

Larva yang baru menetas (D-0) (Gambar 2a) memiliki kisaran panjang dan tinggi total masing-masing $1,56 \pm 0,10 \mathrm{~mm}$ dan $0,44 \pm 0,002 \mathrm{~mm}$ dengan volume kuning telur dan butir minyak $0,056 \pm 0,02 \mathrm{~mm}^{3}$ dan $0,021 \pm 0,002 \mathrm{~mm}^{3}$. Laju penyerapan endogenous baik kuning telur dan butir minyak mengikuti persamaan $\mathrm{y}=0,013 \mathrm{x}^{2}-0,0563 \mathrm{x}+0,0544$ dengan $\mathrm{R}^{2}=0,9456$ dan $\mathrm{y}=0,0029 \mathrm{x}^{2}-0,0157 \mathrm{x}+0,021$ dengan $\mathrm{R}^{2}=$ 0,9928 (Gambar 3). Pada persamaan penyerapan endogenous kuning telur, diketahui membentuk garis parabola. Berdasarkan garis tersebut, maka dapat diartikan bahwa penyerapan endogenous pada kuning telur optimum terjadi pada hari kedua dan maksimum terserap habis pada hari ketiga setelah menetas. Sedangkan pada penyerapan endogenous butir minyak tepat habis pada hari ketiga. Saat di mana larva tidak lagi memiliki cadangan makanan merupakan masa kritis dari larva (Hutapea \& Slamet, 2007), sehingga perlu diberikan pakan tambahan dari luar sebelum memasuki masa kritis. Hal ini dikarenakan kuning telur dan butir minyak merupakan sumber utama nutrien dan energi bagi embrio dan larva. Kuning telur mengandung protein yang kaya akan asam amino seperti (lisin dan arginin, cystine dan cystein, serta tyrosine dan tryptofan), lipid, glycogen, dan atau glycolipid yang diperlukan selama periode menetas hingga periode exogenous feeding untuk membentuk dan mempersiapkan sistem pencernaan, syaraf, muscular, sirkulatori, dan sistem respirasi secara fungsional dalam menerima pasokan pakan pertama kali dari luar (Jaroszewska \& Dabrowski, 2011).

Plankton mulai diberikan pada larva D-2 sebagai green water sedangkan rotifer dan pakan pendukung lain seperti emulsi kuning telur diberikan pada larva umur D-3. Berdasarkan kemampuan makan (feeding ability) pada larva letter six melalui observasi isi perut, diketahui hanya satu atau dua ekor larva dari lima sampel larva yang diambil menunjukkan kemampuan makan yang terlihat dari isi perut yang berisi rotifer. Seiring dengan bertambah usia, jumlah larva letter six semakin menurun dan hanya mampu bertahan maksimum selama 25 hari. Terkait dengan hal tersebut nampaknya rotifer dan pakan pendukung lain seperti emulsi kuning telur bukan merupakan jenis pakan awal yang tepat untuk larva letter six. Berbagai pakan alternatif lain diujicobakan sebagai pakan awal letter six, di antaranya adalah marine cilliata dari jenis Amphorellopsis acuta yang memiliki ukuran 95 (panjang badan) x $32 \mu \mathrm{m}$ (diameter oral) (Nagano et al., 2000) yang apabila dibandingkan dengan rotifer tipe SS memiliki ukuran yang jauh lebih kecil, di mana rotifer tipe SS memiliki kisaran ukuran yaitu 120-140 $\mu \mathrm{m}$ (panjang lorica). Namun, penggunaan jenis Amphorellopsis acuta sebagai pakan awal larva letter six juga belum memberikan hasil yang optimum di mana larva hanya mampu bertahan hingga umur D-9 (Nagano et al., 2000). Nampaknya penggunaan berbagai jenis pakan alami harus terus dieksplorasi untuk mendapatkan jenis pakan awal yang tepat bagi larva letter six.

\section{Pertumbuhan Allometrik}

Pertumbuhan panjang dan tinggi larva letter six mulai D-0 hingga D-25 masing-masing mengikuti hubungan polinomial dengan persamaan $y=0,005 x^{2}$ $+0,001 \mathrm{x}+1,830$ dengan nilai $\mathrm{R}^{2}=0,955$ dan $\mathrm{y}=$ $0,003 x^{2}-0,014 x+0,386$ dengan nilai $R^{2}=0,953$ (Gambar 4). Pertumbuhan ikan sesungguhnya mengikuti persamaan eksponensial di mana laju pertumbuhan terjadi sangat pesat saat awal dan kemudian cenderung melambat pada saat besar dan ketika mencapai usia dewasa pertumbuhan akan terhenti karena energi yang diperoleh dari makanan tidak lagi untuk pertumbuhan melainkan untuk perkembangan gonad. Namun melihat pola pada pertumbuhan panjang dan tinggi pada ikan letter six dari D-0 hingga D-25 mengikuti persamaan polinomial (kuadratik). Melihat pertumbuhannya, ikan letter six merupakan jenis ikan dengan kecepatan pertumbuhan yang rela- 


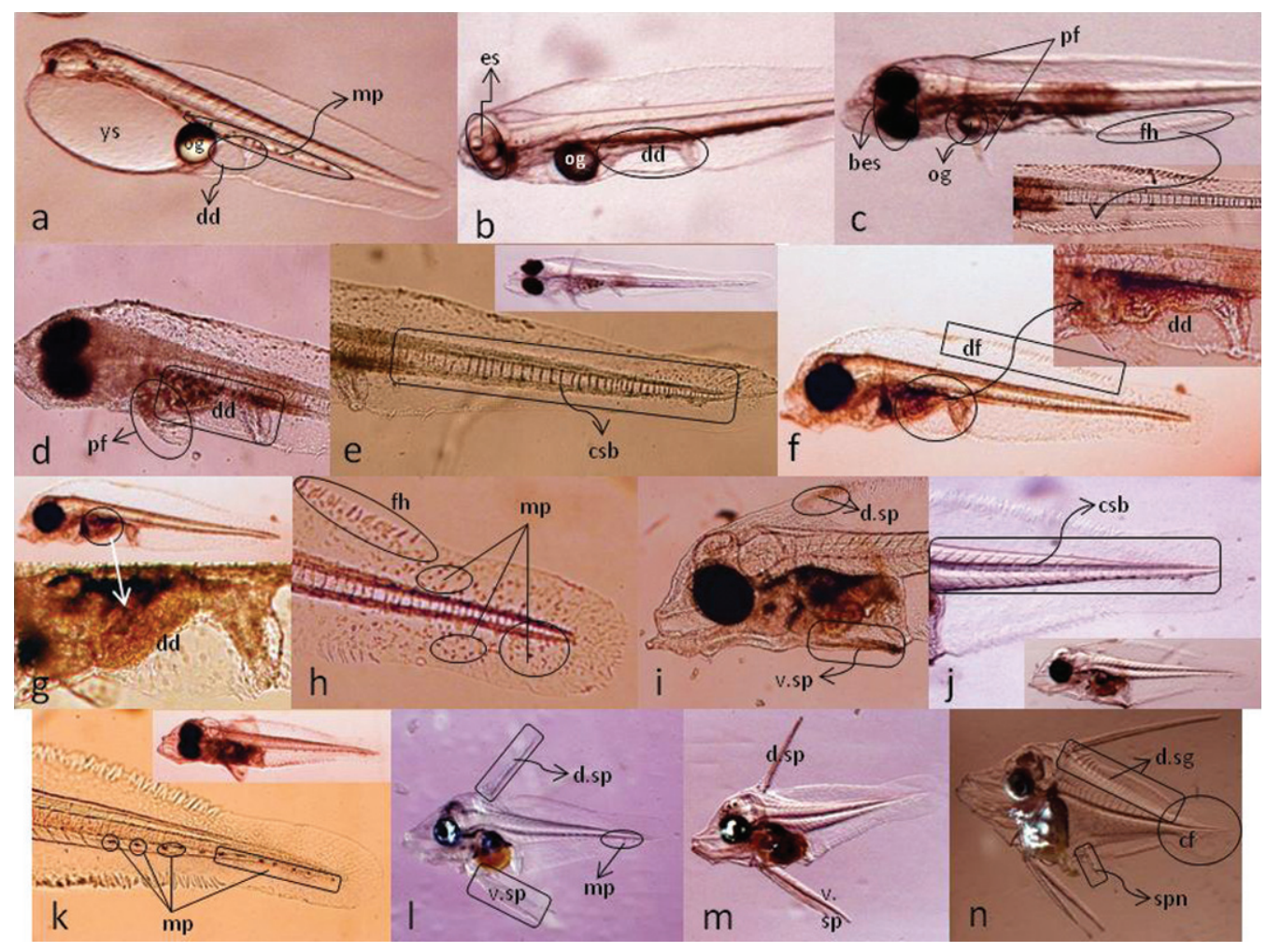

Gambar 2. Fase perkembangan larva ikan letter six. (a) D-0 (4x), (b) D-1 (8x), (c) D-2 (6x), (d-e) D-3 (6x), insert: anterior dan sirip caudal (10x), (f) D-4 (6x), insert: saluran pencernaan (10x), (g-h) D-5 (4x), insert: saluran pencernaan (10x), (h) sirip caudal (10x), (i-j) D-9, (i) anterior (10x), (j) sirip caudal (10x), insert: larva (4x), (k) D-10; sirip caudal (10x), insert: larva (4x), (l) D-14 (3x), (m) D-18 (3x), (n) D-25 (2x). ys (kuning telur); og (butir minyak); mp (melanophore); dd (saluran pencernaan); es (bintik mata); pf (sirip pectoral); fh (bulu halus); bes (bintik mata hitam); d.sp (duri dorsal); v.sp (duri ventral); cf (sirip caudal); spn (duri); csb (tulang segmen pada caudal); d.sg (segmen pada dorsal)

Figure 2. Development phases of letter six. (a) D-0 (4x), (b) D-1 (8x), (c) D-2 (6x), (d-e) D-3 (6x), insert: anterior and caudal fin (10x), (f) D-4 (6x), insert: digestive duct (10x). (g-h) D-5 (4x), insert: digestive duct (10x), (h) caudal fin (10x), (i-j) D-9, (i) anterior (10x), (j) caudal fin (10x), insert: larvae (4x), (k) D-10; caudal fin (10x), insert: larvae (4x), (l) D-14 (3x), (m) D-18 (3x), (n) D-25 (2x). ys (yolk sac); og (oil globule); mp (melanophore); dd (digestion duct); es (eye spot); pf (pectoral fin); fh (fine hair); bes (black eye spot); d.sp (dorsal spine); v.sp (ventral spine); cf (caudal fin); spn (spine); csb (caudal segment bone); d.sg (dorsal segment)

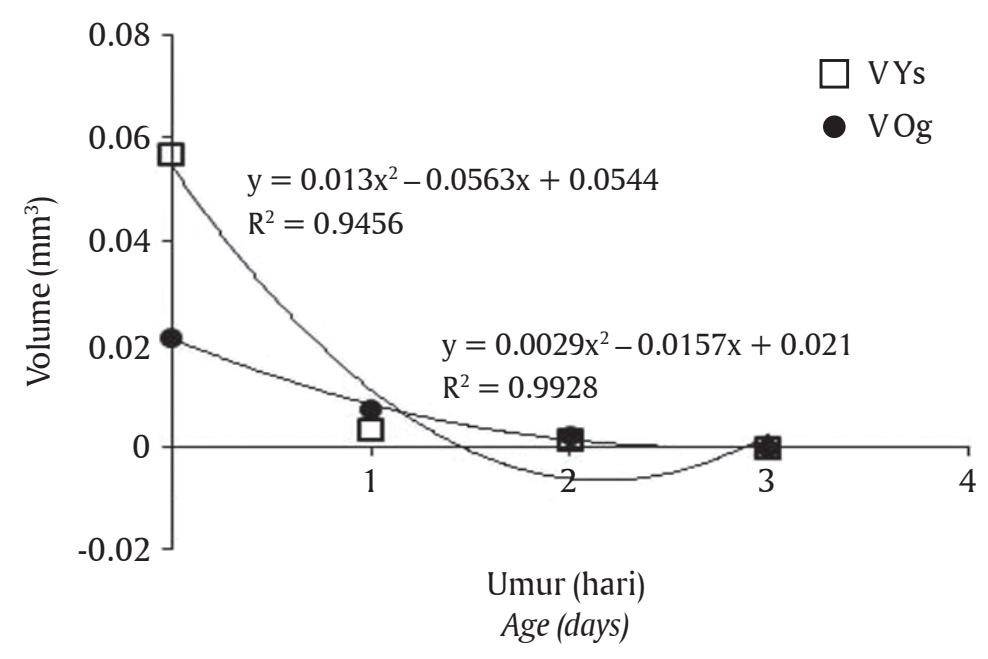

Gambar 3. Hubungan antara umur, penyerapan kuning telur, dan butir minyak pada larva ikan letter six

Figure 3. Relationship between yolk sac, oil globule, and age of larval of letter six 

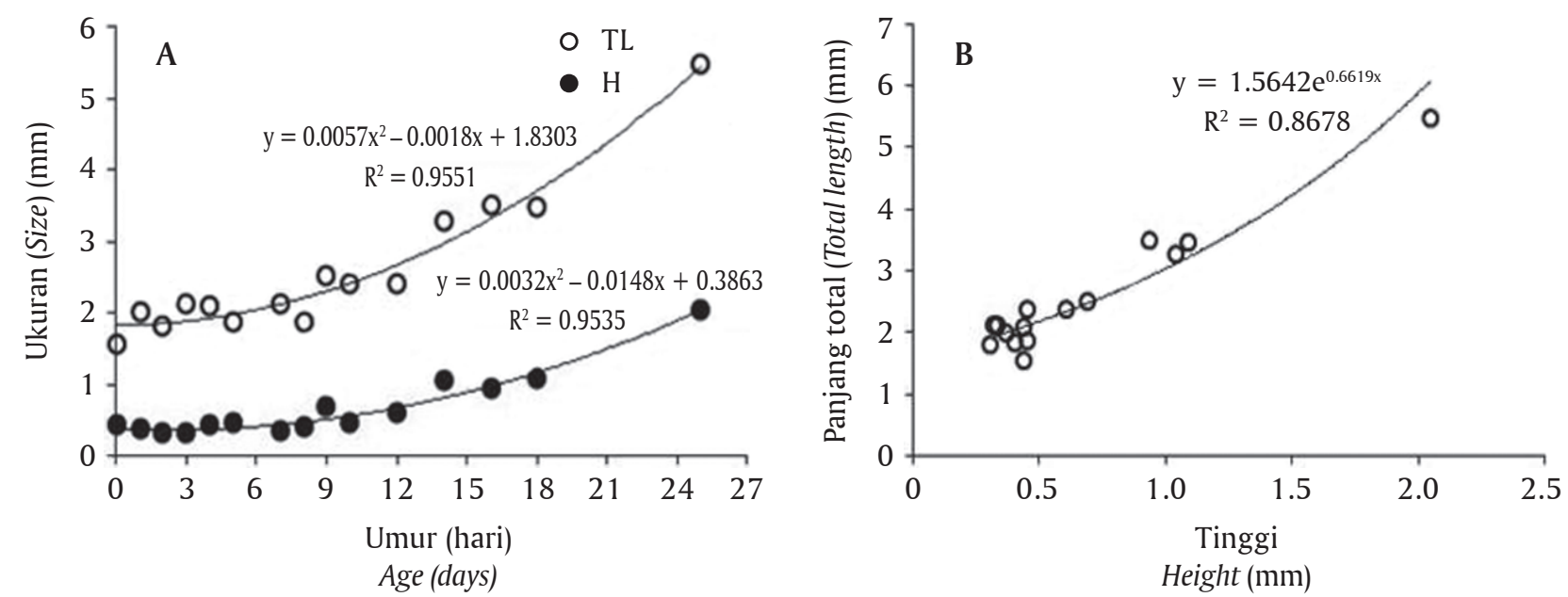

Gambar 4. Laju pertumbuhan panjang dan tinggi larva ikan letter six (A); korelasi pertumbuhan panjang dan tinggi larva ikan letter six (B)

Figure 4. Growth rate in length and height of larval of letter six (A); correlation between length and height larval of letter six (B)

tif lebih lambat di mana larva D-16 mencapai ukuran panjang 3,5 $\pm 0,03 \mathrm{~mm}$. Pada ikan clown ekor kuning (Amphiprion clarkii) yang dipelihara pada suhu normal air laut tropis yaitu $29^{\circ} \mathrm{C}$ larva D-16 mencapai panjang total 8,96 mm (Le et al., 2011), pada ikan hias laut lain yaitu Forktail Blenny (Meiacanthus atrodorsalis) larva D-15 mencapai ukuran panjang 5,45 mm (Moorhead \& Zeng, 2011).

Adapun korelasi pertumbuhan panjang dan tinggi larva mengikuti hubungan allometrik negatif di mana konstanta pertumbuhan $b=0,6629(b<1)$. Hal ini menunjukkan kecepatan pertumbuhan panjang lebih cepat dibandingkan dengan pertumbuhan tingginya.

\section{Perkembangan Morfologi Larva}

Pada larva yang baru menetas (D-0) masih belum terbentuk bintik mata, sehingga larva masih berenang pasif (melayang) di permukaan air. Terdapat melanophore pada bagian tulang badan. Saluran pencernaan masih berbentuk garis memanjang yang sangat sederhana. Pada umur D-0 larva masih mempergunakan cadangan makanan berupa kuning telur sebagai cadangan energi. Memasuki umur D-1 (Gambar 2b) bintik mata sudah terbentuk, namun pigmentasi pada mata belum nampak. Pigmentasi mata terjadi memasuki umur D-2 (Gambar 2c). Pada saluran pencernaan sedikit mulai mengalami perkembangan di mana pada umur D-2 saluran masih nampak garis tipis yang memanjang dan mulai terdapat lengkungan pada bagian posterior anus. Pada umur D-2, pembentukan segmen pada tulang badan hingga ekor mulai terbentuk (Gambar 2c), begitu pula pembentukan sirip pectoral yang juga mulai berkembang di mana terlihat sirip pectoral mulai memanjang dengan kisaran ukuran 0,26 $\pm 0,03 \mathrm{~mm}$ (Gambar 5), sedangkan pa- da bagian dorsal dan ventral dilengkapi dengan tumbuhnya rambut-rambut halus (Gambar 2c). Pada fase ini merupakan fase awal larva mulai menunjukkan aktivitas renang yang lebih aktif.

Memasuki umur D-3 (Gambar 2d), nampak bahwa cadangan makanan berupa kuning telur dan butir minyak telah habis terserap. Seiring dengan habisnya cadangan makanan pada larva D-3-D-5 (Gambar2d-h) mulai memperlihatkan perkembangan saluran cerna yang lebih kompleks diikuti dengan munculnya pigmentasi warna yang semakin gelap di bagian perut larva. Dengan semakin kompleksnya saluran cerna menandakan bahwa larva siap menerima asupan pakan dari luar (feeding exogenous). Seiring dengan terserapnya sumber cadangan makanan endogenous, organorgan pencernaan larva otomatis juga semakin berkembang menjadi lebih kompleks untuk mempersiapkan masuknya pasokan pakan dari luar untuk awal pertama kali (Jaroszewska \& Dabrowski, 2011).

Memasuki umur D-9, segmen-segmen pada tulang ini akan terus berkembang semakin lebar dengan pola segmen yang menyerupai pertumbuhan duri ikan yang sedikit menyerong (Gambar 2j). Pada larva D-9 duri ventral (ventral spine) muncul pertama kali dengan kisaran 0,38 $\pm 0,07 \mathrm{~mm}$ (Gambar 5) dan pada bagian anterior dorsal terdapat bintik duri dorsal (Gambar 2i). Melanophore muncul pada bagian sirip ekor saat larva memasuki umur D-10 (Gambar 2k).

Larva mulai mengalami metamorfosis yang cukup berbeda saat memasuki umur D-14-D-25 (Gambar 2lm). Nampak morfologi larva lebih lebar dan bulat. Pada larva umur D-14, terdapat duri dorsal (dorsal spine) yang mulai nampak memanjang dengan kisaran ukuran $1,01 \pm 0,03 \mathrm{~mm}$ dan pada duri ventral menunjukkan 


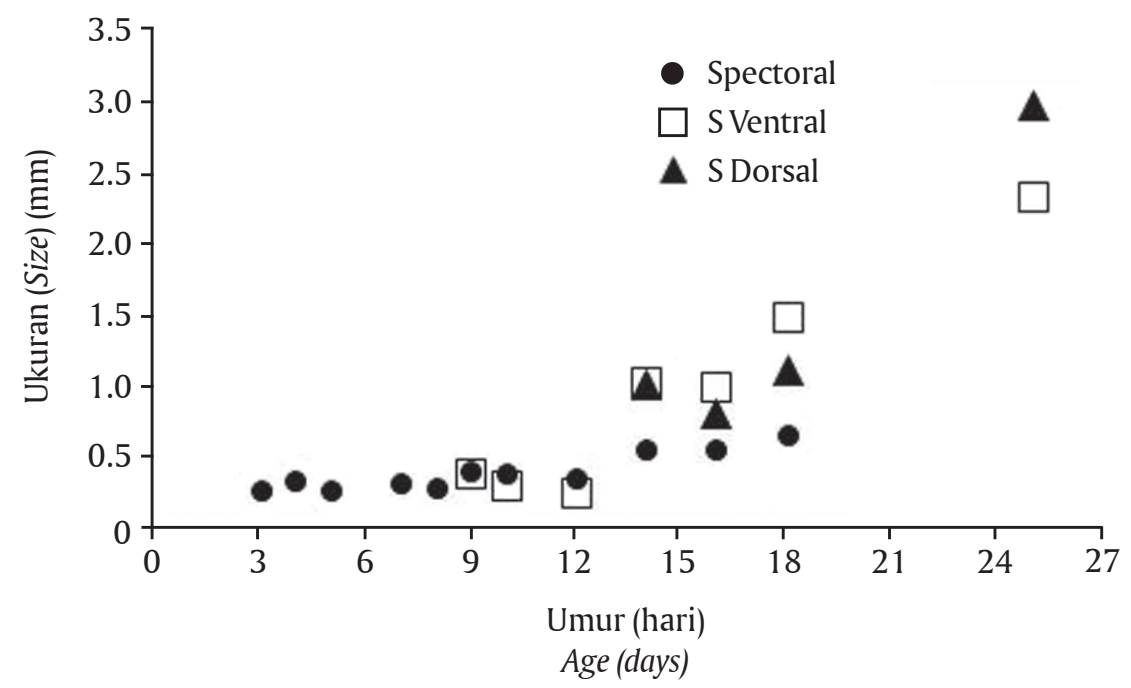

Gambar 5. Perkembangan sirip larva ikan letter six

Figure 5. Fin development of letter six

pertumbuhan yang semakin panjang pula (Gambar 5). Pada bagian perut, terdapat selaput berwarna gelap yang menutupi saluran pencernaan. Memasuki umur D-25, level perubahan semakin sangat besar. Pada bagian badan (body) menunjukkan pertumbuhan yang semakin melebar. Pada bagian dorsal dan ventral mulai memperlihatkan jari-jari sirip yang nampak lebih jelas dan sirip ekor mulai terpisah dari sirip dorsal dan anal. Pada bagian posterior anal muncul duri yang berfungsi untuk melindungi diri saat ikan dewasa nanti (Gambar 2n). Performa larva D-25 menunjukkan morfologi larva yang jauh lebih kompleks.

\section{KESIMPULAN}

Ikan letter six mampu memijah secara alami pada tangki pemeliharaan. Pada suhu $29^{\circ} \mathrm{C}$, perlu menetas setelah 22-24 menit. Kuning telur dan butir minyak habis terserap pada hari ketiga. Plankton mulai diberikan pada larva D-2 (terbentuk bintik mata) sebagai green water, dan pada D-3 (bukaan mulut) mulai diberikan zooplankton yaitu rotifer, pertumbuhan panjang dan tinggi larva mengikuti hubungan allometrik negatif di mana konstanta pertumbuhan $b=0,6629$ (b < 1). Selama pemeliharaan, larva letter six hanya mampu bertahan hidup maksimum hingga D-25. Dengan metode pemeliharaan ini, larva ikan letter six mati pada D-25 sehingga perlu adanya perbaikan metode pemeliharaan melalui pendekatan lingkungan maupun pakan.

\section{SARAN}

Perlu pendekatan dari segi lingkungan (suhu, salinitas, $\mathrm{pH}$, warna tangki maupun air pemeliharaan) yang tepat, serta jenis pakan yang sesuai sebagai langkah perbaikan manajemen pemeliharaan agar perbenihan ikan letter six dapat berhasil dilakukan.

\section{DAFTAR ACUAN}

Allen, G., Steene, R., Humann, P., \& DeLoach, N. (2003). Reef fish identification tropical Pacific. New World Publication. Inc. USA, 484 pp.

Balon, E.K. (2004). About the oldest domesticates among fishes. Journal of Fish Biology, 65, 1-27.

Bonislawska, M., Korzelecka-Orkisz, A., Winnicki, A., Formicki, K., \& Szaniawska, D. (2004). Morphophysiological aspects of the embryonic development of ruffe, Gymnocephalus cernuus (L.) under different thermal conditions. Actha Ichtyologica Et Piscatoria, 34(1), 51-72.

Dhaneesh, K.V., Devi, K.N., Kumar, T.T.A., Balasubramanian, T., \& Tissera, K. (2011). Breeding, embryonic development and salinity tolerance of Skunk clownfish Amphiprion akallopisos. Journal of King Saud University - Science, XXX, 1-9.

Gisbert, E., Merino, G., Muget, J.B., Bush, D., Piedrahita, R.H., \& Conklin, D.E. (2002). Morphological development and allometric growth patterns in hatchery reared California Halibut larvae. Journal of Fish Biology, 61, 1217-1229.

Hutapea, J.H., \& Slamet, B. (2007). Perkembangan morfologi larva ikan kerapu pasir Ephinephelus corallicola (Valenciennes, 1928). Seminar Nasional Kelautan III. Universitas Hang Tuah. Surabaya, hlm. 27-34.

Jaroszewska, M., \& Dabrowski, K. (2011). Utilization of yolk: transition from endogenous to exogenous nutrition in fish. First Edition. John Wiley and Sons. Inc. Larval Fish Nutrition Chapter 6, p. 183-218.

Kusumawati, D., \& Setiawati, K.M. (2010). Profil pemijahan dan perkembangan morfologi larva dan juvenil ikan clown hitam Amphiprion percula.J. Ris. Akuakultur, 5(1), 59-67. 
Le, Y., Yun, Y.S., Ming, Z.X., Min, L., \& Chang, W.K. (2011). Effects of temperature on survival, development, growth and feeding of larvae of Yellowtail clownfish Amphiprion clarkia (Pisces: Perciformes). Acta Ecologica Sinica, 31, 241-245.

Moorhead, J.A., \& Zeng, C. (2011). Breeding of the forktail blenny Meiacanthus atrodorsalis: Broodstock management and larval rearing. Aquaculture, 318, 248-252.

Nagano, N., Iwatsuki, Y., Kamiyama, T., \& Nakata, H. (2000). Effects of marine ciliates on survivability of the first-feeding larval surgeonfish, Paracanthurus hepatus: Laboratory Rearing Experiments. Hydrobiologia, 432, 149-157.

Olivotto, I., Holt, S.A., Carnevali, O., \& Holt, G.J.. (2006). Spawning, early, and first feeding in the lemonpeel angelfish Centropyge flavissimus. Aquaculture, 253, 270-278.

Reksodihardjo, G., \& Lilley, R. (2007). Towards a sustainable marine aquarium trade: an Indonesia perspective. SPC Live Reef Fish Information Buletin, 17, 11-019.

Snedecor, G.W., \& Cochran, W.G. (1989). Statistical method. Eight Edition. Wiley-Blackwell. 503 pp.

Wittenrich, M.L., Turingan, R.G., \& Creswell, R.L. (2007). Spawning, early development and first feeding in the gobiid fish Priolepis nocturna. Aquaculture, 270, 132-141.

Yasir, I., \& Qin, J.G. (2007). Embryologi and early ontogeny of an anemon fish Amphiprion ocellaris.Journal Marine Biology, 87, 1025-1033. 